\title{
Governance and decentralized energy transitions: a comparative case study of three medium sized cities in Sweden, Canada, and the United States
}

\section{Martin BOUCHER}

\section{University of Saskatchewan, Saskatoon, Canada}

\begin{abstract}
:
Aim: This study aims to compare the sociotechnical conditions that contribute to innovative DE projects across five governance dimensions: (1) utility market structure, (2) multi-sector collaboration, (3) decision-making capacity and autonomy, (4) multilevel governance, and (5) public perceptions of climate change. Knowledge of how particular jurisdictions and their governance arrangements influence these transitions can help strengthen and contextualize divergent trajectories of decentralized energy transitions and - most importantly - reveal the role of geographical context in policy change. In particular, this study aims to draw from international comparisons of urban energy transitions.
\end{abstract}

Design: This paper compares the uptake of decentralized energy transitions in three cities in three different countries - Luleå (Sweden), Saskatoon (Canada), and Anchorage (United States). The jurisdictions in each city has unique governance contexts pertaining to electric utilities, regulations, public policy, and public acceptance. By comparing these transitions, this study highlights the governance considerations for decentralized energy transitions and asks how does governance impact the acceleration of decentralized energy transitions in cities? To answer this question, a total of 60 interviews were conducted with actors involved in decentralized energy projects (government, non-forproject, business, utility, academic, and environmental activism). Interview were thematically analyzed with the five governance dimensions.

Conclusion: The conclusions reveal that interactions between the five governance dimensions can partially explain the divergent trajectories of accelerated decentralized energy transitions. In addition to providing a more contextual understanding of these patterns of transitions in cities, the results show that multi-sector collaboration, broad public acceptance for climate change, state or national support for local projects, and local capacity serve as drivers for accelerating decentralized energy in cities. The results also suggest that regulated utility market structures, unstable political cycles, siloed integration of sectors, and decision-making autonomy serve a limited driving role.

Correspondence address: Martin BOUCHER, Johnson Shoyama Graduate School of Public Policy, University of Saskatchewan campus, Saskatoon, Canada. E-mail: martin.boucher@usask.ca Received: 30.07.2019, Revised: 04.20.2019, Revised: 06.02.2020, Accepted: 12.02.2020 doi: http://dx.doi.org/10.29015/cerem.846 
Originality: Much of the literature on decentralized energy and cities has focused on project and sectoral level analysis and hasn't considered the holistic nature of the energy system transition. A particular gap that would help inform a broader understanding is the jurisdictional governance impacts of decentralization energy transitions.

Implications of the research: In practical terms, the results could be used to inform interjurisdictional comparisons of decentralization energy projects. From a theoretical perspective, the results from this research suggest that there should be an elevated importance from the impacts of the interactions of the five governance dimensions.

Limitations of the research: Given that there were three case studies, it is not possible to make generalizable claims from the results.

Keywords: Sustainability transitions, comparative method, urban energy systems, decentralized energy, multilevel governance, energy transitions.

JEL: O13, )16, Q01, R00

\section{Introduction}

Innovative decentralized energy (DE) projects exist around the world - from solar co-ops with unique ownership structures and energy efficient and selfgenerating housing for low income residences to integrated combined heat and power (CHP) systems that also provide community district heating to ambitious wind projects in some of the harshest weather conditions; however, what determines the success of these projects is often unclear. To explain the drivers and challenges of DE transitions, researchers have developed theories, models, and various types of analysis. Some have argued that DE projects are successful because of a combination support in the form of subsidies, research and development, or regulations (Kemp et al. 1998). Others have argued that DE innovation works when competitive market forces are unleashed, government intervention is minimal, and public support is high. ${ }^{1}$ Yet another view claims that it is sustainability networks that drive these unique local energy innovations (Seyfang et al. 2013). Motivated by the pursuit for sustainability, the environmental community takes on projects and pushes its agenda on the public and private sector.

\footnotetext{
${ }^{1}$ The academic literature generally does not support the idea that only market forces can be used to drive decentralized energy - there is a general consensus that government intervention at some level is required. This sentiment, however, more often prevails in mainstream discussions on energy transitions.
} 
A robust interdisciplinary literature on sustainability transitions (Markard et al. 2012; Köhler et al. 2019), integrating expert knowledge from varied disciplines, has rapidly developed around these questions. This "socio-technical" approach has led to insights for pathways to overcome some of society's most contentious problems: overconsumption, GHG emissions, ocean acidification, social justice, and, of course, climate change. Despite these insights, most studies on sustainability transitions of DE have focused on single jurisdictions, with little research comparing how different cities in different countries handle transitions. Of the few comparative studies on multiple jurisdictions, even fewer have investigated the governance factors of integrating DE into their energy systems. Building on the literature on sustainability transition theories, governance, and urban local energy innovation, this current study compares three medium-sized cities. Often overlooked in the literature, medium-sized cities have unique constraints and opportunities that make them ideal for such an analysis. On this basis, the paper asks the question: How does governance impact the acceleration of decentralized energy transitions in cities? To investigate this question, stakeholders $(n=60)$ involved with each city's local energy system and decentralized energy projects (government, non-for-project, business, utility, academic, and environmental activism) were interviewed. This paper compares these results using five governance dimensions: (1) utility market structure, (2) multi-sector collaboration, (3) decision-making capacity and autonomy, (4) multilevel governance, and (5) public perceptions of climate change. After a discussion on the theoretical implications of the results, this paper concludes with recommendations for further research.

\section{Cities and energy}

Half the world's population now live in urban spaces, a demographic trend that is predicted to continue (United Nations 2010, 2018; Jiang, O’Neill, 2017). By 2050 the world's population is expected to be 9.6 billion, 68\% in cities (United Nations $2010,2018)$. Although only $2 \%$ of the world's landmass is urban, these areas produce approximately two thirds of the GHGs (IEA 2009). According to the IPCC 
(2007), half of all energy use and GHG emissions come from the built environment (IPCC 2007) as buildings consume substantial energy and emit high emissions (Akorede et al. 2010; Hughes et al. 2011). However, the projected increase in urbanization presents an opportunity to reduce energy demand (Lin, Ouyang 2014). For instance, the concentration of energy use intensity and public use of infrastructure creates opportunities to significantly reduce emissions.

Cities have potential to be drivers of innovation in the energy transition. Often centers of social progress, grassroots action, and experimentation, many cities are leading the fight against climate change (Bulkeley, Metsill 2003; Betsill, Bulkeley 2004, 2007; Wurzel et al. 2019). For cities, the energy transition is an opportunity to both reduce global emissions while creating opportunities of local autonomy and resiliency. National and international levels of government and policies have begun to recognize the importance of cities and their role in emissions reduction (Betsill, Bulkeley 2004; Chittum, Østergaard 2014; Compact of Mayors 2015). Instead of waiting for national and international signals for environmental action, they are often flexible enough to transition quickly to renewable energy (Droege 2002) and are seeking ways to augment their local and alternative energy portfolios, particularly DE (Mulugetta et al. 2010).

Despite these initiatives, developing and implementing local DE projects in cities is not a simple matter. A shift to DE is multidimensional, with intersecting social, economic, political, and technological factors to be considered (Hodson, Marvin 2009; Lesage et al. 2010). Although at all levels of government, energy is an increasingly challenging policy question, local entities, in particular, are often ill equipped to manage the challenge of energy governance (Florini, Sovacool 2009). Technical problems are also challenging. Engineers are building an understanding of urban energy system models and learning how to integrate a portfolio of energy options within an urban context (Keirstead et al. 2012). Urban issues and energy technologies, as a socio-technical system, should be the focus of further research (Hommels 2005). In particular, a focus on gaining insights from stakeholders within local energy systems will better expose the challenges and opportunities of these complex interactions. 


\section{The comparative method and case study selection}

The comparative method is an established and growing research approach (Mill 1843; Tilly 1984; Rihoux et al. 2013; Ragin 2014). This method can unlock causal patterns within complex systems (Byrne 2005) necessary for comparative studies with few cases (Ragin 2014). The following cities were selected: Saskatoon (Canada), Luleå (Sweden), and Anchorage (United States). Table 1 compares key aspects of these cities relevant to the case study.

Table 1. Comparative case study city selection

\begin{tabular}{|c|c|c|c|}
\hline & Saskatoon & Luleå & Anchorage \\
\hline Country & Canada & Sweden & United States \\
\hline $\begin{array}{l}\text { Population } \\
\text { (Urban) }\end{array}$ & 246376 & 75832 & 291538 \\
\hline Area & $170.8 \mathrm{~km}^{2}$ & $29 \mathrm{~km}^{2}$ & $204 \mathrm{~km}^{2}$ \\
\hline Density & $13001 / \mathrm{km}^{2}$ & $2619 / \mathrm{km}^{2}$ & $1232 / \mathrm{km}^{2}$ \\
\hline $\begin{array}{l}\text { Sunshine } \\
\text { Hours in } \\
\text { December }\end{array}$ & 86.5 & 3 & 51.8 \\
\hline $\begin{array}{l}\text { Average } \\
\text { Temperature } \\
\text { Range } \\
(\text { Jan/July) })^{2}\end{array}$ & $-18.9^{\circ} \mathrm{C} / 25.7^{\circ} \mathrm{C}$ & $-12.9^{\circ} \mathrm{C} / 20.7^{\circ} \mathrm{C}$ & $-11.4^{\circ} \mathrm{C} / 18.6^{\circ} \mathrm{C}$ \\
\hline Latitude & $52^{\circ} 08^{\prime} \mathrm{N}$ & 64'34' 4'” N & $61^{\circ} 13^{\prime} \mathrm{N}$ \\
\hline $\begin{array}{l}\text { Local and } \\
\text { Regional } \\
\text { Electric } \\
\text { Utility }\end{array}$ & $\begin{array}{l}\text { Saskatoon Light and } \\
\text { Power, SaskPower }\end{array}$ & $\begin{array}{l}\text { Luleå Energi, Nordic } \\
\text { Energy Market }^{3}\end{array}$ & $\begin{array}{l}\text { Anchorage Municipal } \\
\text { Light and Power, Chugach } \\
\text { Electric Association, } \\
\text { Matanuska Electric } \\
\text { Association }\end{array}$ \\
\hline $\begin{array}{l}\text { Electric } \\
\text { Utility } \\
\text { Ownership }\end{array}$ & $\begin{array}{l}\text { Public/ GTD } \\
\text { Provincial Monopoly }^{4}\end{array}$ & Public & Public and Cooperative \\
\hline Heat Type & Gas (minimal electric) & District CHP & $\begin{array}{l}\text { Gas/Electric (minimal } \\
\text { wood and oil) }\end{array}$ \\
\hline $\begin{array}{l}\text { Notable DE } \\
\text { Projects }\end{array}$ & $\begin{array}{l}\text { SES Solar Coop, } \\
\text { Renewable Rides }\end{array}$ & LuleåKraft CHP, Biogas & $\begin{array}{l}\text { Fire Island Wind, Low } \\
\text { Income Housing Project }\end{array}$ \\
\hline
\end{tabular}

Notes:

1. Based on average low for January and average high for July.

2. The major companies are Vattenfall, Fortum, Statkraft, E.on, Elsam, and Pohjolan Voima. Source: Statistics Canada (2016); United States Census Bureau (2019); Luleå Kummun (2020). 
Several considerations informed the selection of these three cities: population size and density, location, experience with previous DE projects, language, and governance of local utilities. Medium sized cities of 50,000 to 300,000 from different countries were selected because cities of this size typically have the capacity to pursue innovative projects, lack the land use constraints of larger cities (Gargan 1981; Andrews et al. 2016) and are exposed to a similar range of DE technologies. By selecting cases that would presumably have the potential to pursue DE technologies in their city, a comparative approach can more precisely contrast the success and failures of projects. The cities chosen were in the north because northern cities have attributes that can be held constant in a comparative analysis such as the northern latitude, seasonal temperature variances, seasonal changes to sunlight hours, and cold temperatures. All the cities have predominately rural and low regional population densities and, because they are relatively isolated, are not influenced by the proximity of larger urban centres. Another consideration was commitment to reducing GHG emissions and experience with DE; all three cities selected had implemented at least two DE projects. For practical data collection purposes, English was spoken by all interviewees in the selected cities. Finally, the municipal governments of all three cities have public ownership in their local electric utilities.

In addition to similarities, differences among the cities enhanced their suitability for a comparative case study analysis. All have varied utility ownership structures, social cultural conditions, political systems, energy policies, and current implementation levels of DE. From a governance perspective, all three cities have highly different electricity systems. Saskatoon owns its own electricity distribution, although the province in which it is located - Saskatchewan - operates the majority of the generation, transmission, and distribution (Hurlbert et al.; Hurlbert et al. 2019). In Luleå, the electricity utility is integrated into a competitive Nordic energy market that includes Sweden, Demark, Finland, and Norway. In Sweden, the majority of electricity generation comes from hydro (44.1\%) and nuclear (40.5\%) (IEA 2013). Anchorage Municipality operates a local utility for the downtown core, while two regional cooperatively owned utilities serve the remaining portions of the city and surrounding area. Unlike Sweden and Saskatchewan, Alaska does not have 
an integrated and centralized electricity system that serves the entire region; instead, there are competing utilities with regional interconnections across the Alaska Railbelt. $^{2}$ The three utilities in Anchorage operate as independent, verticallyintegrated utilities, each with its own generation, transmission, and distribution networks within their respective districts.

\section{Data collection and interview methods}

A total of 60 interviews were conducted with actors involved in DE projects (government, non-for-project, business, utility, academic, and environmental activism). Along these lines, stratified sampling was used to allow for intersecting perspectives from interviewees (Robinson 2014). To ensure interviewee participation and comfort, interviews remained anonymous (Tilley, Woodthorpe 2011; Saunders, Kitzinger 2015; Lancaster 2017). A non-probabilistic sample size was used for each of the city case studies based on achieving data saturation. (Glaser, Strauss 1999; Fossey et al. 2002; Hennink et al. 2017). Saturation is the point at which no additional insights are garnered from the data collection (Baker et al. 2018). Although saturation is essential in qualitative research (Moore, 1995), it is a subjective form of analysis; therefore, scholars have pointed out that research needs to be transparent and specific about what is meant by saturation (Morse 1995; Guest et al. 2006; Hennink et al. 2017) and operationalize the saturation process (Malterud et al. 2016; Aldiabat, Le Navenec 2018). This saturation method includes provisions such as aim, sample specificity, use of theory, quality of dialogue, and analysis strategy as factors in determining sample size (Malterud et al. 2016). Table 2 outlines the details of the information power analysis that was conducted to reach sample size saturation.

\footnotetext{
${ }^{2}$ The Railbelt is a regional electrical grid that connects seven utilities in the most population region in Alaska from Fairbanks, to Anchorage, and the Kenai Peninsula. Three of the seven utilities serve the City of Anchorage: MEA, ML\&P, and Chugach.
} 
Table 2. Information power sample size saturation

\begin{tabular}{|l|l|l|}
\hline Criteria & Details related to study & Saturation metric \\
\hline Aim & $\begin{array}{l}\text { Broad: To compare the } \\
\text { sociotechnical conditions that } \\
\text { contribute to innovative DE projects }\end{array}$ & $\begin{array}{l}\text { Enough interviews were conducted to } \\
\text { inform the overall aim of the research }\end{array}$ \\
\hline $\begin{array}{l}\text { Sample } \\
\text { Specificity }\end{array}$ & $\begin{array}{l}\text { Dense: Actors are limited to those } \\
\text { with knowledge or connection with } \\
\text { energy projects in their respective } \\
\text { city. }\end{array}$ & $\begin{array}{l}\text { Include actors from multiple sectors } \\
\text { (political, business, advocacy, etc) that } \\
\text { represent the major components of the } \\
\text { energy system of each case study }\end{array}$ \\
\hline Use of Theory & $\begin{array}{l}\text { Applied: Results will be used to } \\
\text { develop theory }\end{array}$ & $\begin{array}{l}\text { Enough interviews were conducted to } \\
\text { answer the research question }\end{array}$ \\
\hline Dialogue & $\begin{array}{l}\text { Strong: Interviewer is very } \\
\text { knowledgeable on topic and with } \\
\text { conducting interviews. On-site face- } \\
\text { to-face interviews to be used. }\end{array}$ & $\begin{array}{l}\text { Individual interviewees have no } \\
\text { additional comments to share on the } \\
\text { topic }\end{array}$ \\
\hline Analysis Strategy & $\begin{array}{l}\text { Cross-case: This is a comparative } \\
\text { study with three cities. }\end{array}$ & $\begin{array}{l}\text { Enough interviews so that thematic } \\
\text { analysis could be conducted between the } \\
\text { case studies. }\end{array}$ \\
\hline
\end{tabular}

Notes:

1. Selection of participants was based on background research on their involvement with the local energy system and their suitability for the study aim.

2. A semi-structured interview guide was development in accordance with quality qualitative semistructured interview methods of "(1) identifying the prerequisites for using semi-structured interviews; (2) retrieving and using previous knowledge; (3) formulating the preliminary semi-structured interview guide; (4) pilot testing the interview guide; and (5) presenting the complete semi-structured interview guide" (Kallio et al. 2016: 2961).

3 . In the case that more information was needed to be shared than an additional interview was conducted with that participant or follow up questions were asked.

4. Face-to-face hour-long dialogues were used for the majority of the interviews. As well the majority of the interviews were conducted at the interviewees' place of work. All interviewees were provided an information sheet on the project prior to the interview so they could be appropriately prepared for the interview.

5. Prior to conducting the interviews in each of the case study cities, thorough background research was conducted. This included in-depth documents analysis of academic and non-academic literature including books, reports, council minutes, official government website entries, and news articles.

Prior to starting the research, it was determined that a target of 15 interview participants for each city would meet the saturation requirements. Although an interview target was established, achieving information power saturation was the goal. For instance, in Anchorage $(n=32)$ the sample size was double that in Saskatoon $(n=12)$ and Luleå $(n=16)$ because it was more difficult to achieve saturation. To buttress interview saturation, contemporaneous notes and journaling were also used during the interview process to ensure key insights and gaps in knowledge were accounted for (Janesick 1999; Watt 2007; Ortlipp 2008; Annink 2016). I conducted month-long site visits to better understand the cultural contexts 
that may have impacts on the institutions, norms, and organizations of the cities. ${ }^{3}$ Face-to-face hour-long dialogues were used for the majority of the interviews. Where face-to-face interviews were not at option, telephone interviews were used instead. Research on telephone interviews has demonstrated that they are an effective alternative to face-to-face interviews for data collection (Watt 2007; Holt 2010; Block, Erskine 2012; Schober 2018).

\section{Results and analysis}

I conducted a thematic analysis specific to governance considerations from the interviews, journal entries, and city specific academic and grey literature. From this analysis, I selected five governance dimensions that impact DE transitions in cities: utility market structure, multi-sector collaboration, decision-making capacity and autonomy, multilevel governance, and public perceptions of climate change.

\subsection{Utility market structure}

Each of the cities operated within various utility ownership structures, regulated or deregulated electric utility markets, which had implications for DE transitions. Luleå's electric utility competes within the Nordic energy system. Anchorage has three vertically integrated electric utilities, two cooperatively owned and one municipally owned. Saskatoon has both a municipally owned utility for a portion of the city connected to a larger monolith vertically integrated crown corporation that serves the province of Saskatchewan. Interviewees in all of the cities noted a variety of opportunities and challenges with their jurisdiction's utility structures.

Of the three cities, Lulea is the only one that must compete within a deregulated market. Although Luleå owns its local electrical distribution utility, it is integrated into the broader Nordic energy market, or the Nordic Synchronized Area. For local energy in the city, the market structure provides an assortment of benefits, one of which is the potential for deregulated markets to better manage the challenge of intermittency. The ability to sell electricity in peak generation times when local

\footnotetext{
${ }^{3}$ The lead researcher and author of this paper resides in Saskatoon.
} 
demand is low increases the value of DE to the grid. An energy expert in Lulea noted that, "The reason why we can do the CHP is maybe that we can [...] sell electricity on the grid" (Luleå Interview \#10). The same interviewee noted that "it's not that the city balances the power grid. They care about the district heating. That one they have to supply because district heating is local, but the power they sell to the spot market" (Luleå Interview \#10). By selling electricity to the spot market, Luleå is able benefit from its overproduced electricity, allowing projects like Luleå's CHP system to be viable. Within the Nordic Synchronized Area, hydropower and pumped hydro storage, located in Norway and Sweden can serve as storage to balance local intermittent DE projects.

Saskatoon and Saskatchewan have a traditional regulated market. Although there are peaks and valleys in the demand profile in Saskatchewan, there is no spot market or capacity market within the system that local energy projects can leverage. In the Saskatchewan context with its regulated market, the financial justification for self-generation in community and roof-top solar is different. ${ }^{4}$ From the perspective of the electrical utility, DE can be antagonistic to its profitability and business model (Dolter, Boucher 2018). An energy expert in Saskatoon noted that there is a fundamental business challenge to the local utility to sell electricity with the current net metering program.

There's absolutely no benefit to Light and Power [SL\&P]. So, for every kilowatt solar panels that are installed, Light and Power [SL\&P] loses money. So, with the production it does mean, so whatever's coming on, whatever's not used onsite and comes onto the grid through the net meter that does offset bulk power purchases. But it also eliminates that revenue opportunity for Light and Power [SL\&P]. If you take the loss revenue opportunity and you subtract the avoided bulk power purchase, it's still a significant net loss for every kilowatt of solar that comes on the grid (Saskatoon Interview \# 9).

Similarly, another energy expert mentioned that there is an economic challenge to local energy development from the perspective of SL\&P.

\footnotetext{
${ }^{4}$ A forthcoming paper will provide an analysis of the policy landscape and decision-making challenges from the perspective of the utility of self-generation programs in Saskatchewan.
} 
[I]t's not quite as clearly defined as their [SL\&P] mandate to make money. And the mandate to make money for the utilities is somewhat in conflict with the mandate to do renewable energy projects because... they buy most of their electricity from SaskPower for pretty cheap (Saskatoon Interview \#2).

One of the major issues for intermittent renewable energy in a regulated market is cross-subsidization. In fact, a report to council in Saskatoon from the local utility noted that, "The financial impact for each kilowatt of solar installed is estimated to be a reduction in revenue of $\$ 185.25$ per year. With these programs doubling in size every two years, the financial impact continues to grow proportionally. The loss of revenue opportunity from the existing programs in 2017 was estimated at $\$ 92,625$ " (City of Saskatoon 2017). ${ }^{5}$ A deregulated market structure for DE can create an economic environment that better manages the issues of cross-subsidization.

The utility landscape in Anchorage and Alaska is disjointed and, in some instances, dysfunctional. Whereas Luleå's jurisdictions are deregulated and interconnected and Saskatoon's are interconnected and regulated, Anchorage's are neither. Discussed widely during the interviews in Anchorage was the lack of cooperation between the utilities along the Railbelt and the need to move towards a consolidated model that rationalizes the transmission system discrepancies. A government official discussing the seven Railbelt utilities noted that,

Each organization [Railbelt utility] grew up as a standalone organization, right? And then you operate them together. You look at it, well that's nuts. Well you would never have designed it that way if you just designed it altogether (Anchorage Interviewee \#7).

The interviewee continued by arguing that, "there are significant savings to be had by operating this unit as one" despite the "disagreement between utilities" (Anchorage Interviewee \#7). Because of the lack of cooperation between the

\footnotetext{
${ }^{5}$ The issue of solar cross-subsidization in Saskatchewan was analyzed in more depth by Dolter and Boucher (2018).
} 
Railbelt ${ }^{6}$ utilities in Alaska, there is overcapacity embedded within the entire system. Interviewees emphasizes that this lack of integration has resulted in overcapacity buildup that would otherwise be required if there was greater integration between the utilities (Anchorage Interviewees \#2, 6, 7, 13, 14 17, and 24).

As it pertains to DE in Anchorage, a lack of integration between the utilities creates obstacles.

For instance, according to the Committee on Railbelt Operating and Reliability Standards "to the extent practical, interconnecting entities should not be allowed to degrade the performance or reliability" (The Intertie Management 2017). Reliability is challenged by the uptake of DE on the grid. A business leader in Anchorage noted that,

The utilities for the longest time were not particularly friendly to the idea of somebody undermining their business case by reducing the amount of energy that they're purchasing from the utility. Now they're trying to kind of thread the needle and they recognize that their consumers will not accept that. So now they're trying to figure out what new technologies, how to do net metering more effectively, and then how to balance that with the cost of their existing grid. Because again, you know [...] now you've got the consumer electric grid, which is residential, commercial and some industrial in anchorage. Okay. So, who's paying to maintain that grid? (Anchorage Interview \#2).

Similarly, a representative from one of the utilities in Anchorage noted that,

If there's a dip in the availability of wind because of a gust or because the wind falls off, it's harder for our system to absorb those fluctuations. And so, we then have to have more reserve capacity online. We have to have

\footnotetext{
${ }^{6}$ As of February of 2019, four of the Railbelt utilities, included all of the Anchorage utilities made a request to the RCA for the formation of a transmission utility (Company 2019).
} 
more fossil generation. How we handle it, right now, we have more fossil generation spinning, which means that the economics aren't as good because we still have to be burning fuel (Anchorage Interview \#13).

In response to the growing concern of the transmission system in Alaska, the Regulatory Commission of Alaska (RCA) has requested that the Railbelt develop a model in which the utilities increase cooperation. This is not a new discussion and there has been a longstanding debate between the seven utilities in Alaska connected in the Railbelt on models for integration. As early as 1998, a report prepared for the Alaska Public Utilities Commission highlighted the importance of power pooling and central dispatching (Alaska Public Utilities Commission 1998). Interviewees also emphasized that integration would allow Anchorage to sell its excess and relatively inexpensive electricity to Fairbanks, also connected to the Railbelt, which is experiencing higher electricity costs. Integration of the utilities would allow for greater penetration of DE on the gird in Anchorage.

\subsection{Multi-sector Cooperation}

Sweden, Saskatchewan, and Alaska have differing approaches to multi-sector cooperation and these differences impact local DE projects in Luleå, Saskatoon, and Anchorage. According to the interviewees, Luleå had a high level of multi-sector cooperation between public and private entities, whereas Anchorage and Saskatoon had a low level of integration.

The extent to which there was multi-sector cooperation was a source of success for projects in Luleå. Interviewees attributed their cooperation to the success of their DE projects. A political leader in Luleå emphasized that this integration has impacted the political scene in the city and opportunities for local energy innovation.

The steel production is the backbone of the city [...] Everybody who lives in the city, and especially we who are in the ruling party, understands the importance of the industry and the need to find the collaboration with the industry in different ways. So I think that over the years, the solutions that have been made that are many of them, before I was born or before I 
was active in politics, they are made of the, of the mutual trust that the city and, and the industry has an extremely strong link between each other and the necessity to understand the work together (Luleå Interview \#15).

A business leader in Luleå similarly emphasized how production processes are adapted to adjust to heating demand profiles in the city. As well, this business leader discussed the importance of maintaining steady production for the city during the coldest days in the winter to ensure that the city's district heating system has enough heat to continue operations.

We have for many reasons to avoid [having] stops in production if it's very cold outside. But one of the reasons is that we really need energy to the heating system for the town [Luleå] for when it's cold outside. There are other reasons. [...There is a] risk of freezing up parts of the plant here if it's too cold outside and we have a stop. We also have to think of [...] supply[ing] the district heating (Luleå Interview \#12).

Long-term agreements were often part of the multi-sector cooperation in Luleå. An energy expert in Luleå emphasized that long-term agreements between the public and private sector were important for the success of the existing district heating network that exists in the city.

The fact that we did compile a really long-term agreement early on in the process when it comes to the price of the waste gas [...] they put a very low price to begin with on the waste gas. Because [it is a] local energy company, we're supposed to be given the opportunity to invest in the district heating network. They had to allow this because there were no district heating network. There were small networks in the new built housing areas and perhaps here in there, but they had to build all those together and the steelworks found that reasonable (Luleå Interview \#8). 
Whereas Luleå had a managerial approach to its integration, Anchorage and Saskatoon had a more facilitation role. This is not to say that there are no partnerships in Saskatoon and Anchorage, but the breath and the long-term nature of the partnerships are not as prevalent. To this point, a business leader in Anchorage noted that, "the energy base of Anchorage and the region has kind of grown up organically over time without really any significant long-term planning until the last 20 years" (Anchorage Interview \#2). What has resulted from this has been a more siloed approach. Similarly, in Saskatoon, the interconnections between the public and private sector are more limited. Recently, however, there have been notable projects Saskatoon and Anchorage - the Fire Island Wind project in Anchorage and the SES Community Solar project are both such examples.

Although Luleå has had much success with multi-sector cooperation, there was a perception amongst interviewees that there were few new actors entering the system. When asked if there were new actors in the energy system in their city in the last 10 years, interviewees in Saskatoon and Anchorage said that there were many new actors while most interviewees in Luleå mentioned that there were none in their city. In Saskatoon and Anchorage, interviews emphasized that there were many new businesses in all areas of the energy system. This contrasted Luleå where there was little mentioned of new businesses.

\subsection{Decision making capacity and autonomy}

Each of the cities have different levels of autonomy relative to their decision making. Anchorage has a strong mayoral form government, Saskatoon has less mayoral powers with a stronger council, and Luleå has a cabinet-based government, which operates as a party-based legislative municipal assembly. ${ }^{7}$ Despite the strong mayoral form of government in Anchorage, local decision making on energy is spread among the three utilities through membership cooperative boards. This gives the cooperative utility board much autonomy to make decisions, which was highlighted as an opportunity. On the topic of this co-op system, a political leader in

\footnotetext{
${ }^{7}$ The mayoral form distinction exists primarily in the United States. Cities in Sweden and Canada don't have this distinction.
} 
Anchorage noted the following when comparing the ML\&P (the municipally owned utility) and the utility co-ops:

It $[\mathrm{ML} \& \mathrm{P}]$ is run like a separate individual utility and in fact it has profit requirements. It has to generate a certain amount of value for the municipality. The co-op model has a lower requirement and in fact the coop model for energy production if it's done properly the intent there is to keep prices low. That's actually its core mission is to generate power as cost effectively as possible. So, it's that non-profit model but with a strong value on keeping the price proper [...and] competitive (Anchorage Interview \#1).

A business leader in Anchorage emphasized the decision-making autonomy of Anchorage and how the city is motivated to move forward with energy efficiency regulation.

The state has no authority to any significant degree. They grant a broad set of brush stroke authorities that a city can adopt, but they leave it to the cities to choose what parts that they're going to adopt. Plus, there are national standards that are related to insurance that have to be adopted and finance that have to be adopted. So, you've got a fairly complex set of things that are influencing a city policy on building codes and energy efficiency. That's an interesting interaction. Well part of it is the city's got a motivation in this and the fact that they want their citizens to have more money in their pocket books so that there'll be a little more willing to. It also increases the value of the homes so your tax base goes up (Anchorage Interview \#2).

Ownership over the local utility was emphasized as an opportunity for local DE project. A political leader in Saskatoon on the role of SL\&P noted that,

I think there's a risk by us not being out in front providing opportunities for people to do things like solar because we're moving in that way. And I think 
if we're not part of that conversation, then we lose out on all of that revenue as well (Saskatoon Interview \#3).

\subsection{Multilevel governance}

The impact of policies from state, provincial, federal, or national government was emphasized as important by the interviewees in each of the cities. In Saskatoon and Anchorage cities are creations of the province or state, respectively. Therefore, the federal governments in Canada and the United States have a limited direct impact on city autonomy. This contrasts with Luleå, where cities are with the jurisdiction of the national government. Therefore, the national government of Sweden has much greater impact on cities. There are a number of ways that higher level governments can support DE. However, supportive policies were perceived as less or more stable in each of the jurisdictions, which impacted decisions on DE projects.

Whereas Luleå has been a paragon of policy stability and support, the dynamic in Anchorage was one of a fluctuating policy environment. In the state of Alaska, a large portion of public revenues are from the natural resources sector. Since 2008, the price of oil has fallen and so to have the revenues associated with that support (Alaska Department of Revenue 2017).

In Anchorage for instance, there is financial support from higher level governments for tax credits. In particular, part of the justification for the energy efficiency and renewable energy projects for the Cook Inlet Housing Authority support through the Greater Opportunity for Affordable Living (GOAL) program. The GOAL program is applied based competitive process between developers of low to medium income housing that is administered by the Alaska Housing Finance Corporation (AHFC). As part of the selection process, points are allocated for the provisioning of conservation and renewable energy initiatives (Alaska Housing Finance Corporation 2018). An interviewee noted that, "One of the reasons why we do alternative energy is to get points to build these projects, right? Because our end goal in this whole thing is to create homes for people. So, to do that, we got a win money. And to do that we've got to do alternative energy because we get points for it" (Anchorage Interview \#21). The same interviewee emphasized that the 
environment for funding has become increasingly competitive and funds are more difficult to receive.

\subsection{Public perceptions of climate change}

Public support for environmental initiatives and norms around climate change differed in the jurisdictions of each of the cities. At the city level, there were targets for emissions reductions under the Compact of Mayors. Public support for climate change within a jurisdiction can have positive impacts on the uptake of local DE projects. In the interviews, climate change was mentioned as a major driver in Luleå but not in Anchorage and Saskatoon.

When discussing the steel business and the CHP system in Luleå, a business leader emphasized that the steel industry is strongly motivated to reduce its emissions.

Not only from the government but $[\ldots]$ the climate discussions $[\ldots]$ there is of course the pressure to reduce the climate impacts. And, as we are one of the major emitters of carbon dioxide in Sweden to reach the goals that are set up by the politicians we [the steel industry] have to do something (Luleå Interview \#12).

A political leader in Luleå mentioned that there is political support for spending public funds on climate change, "I think that we have to take the tax money [...] to help climate change so that our generations after us could stay [and] live here on this planet (Luleå Interview \#7). These sentiments about the importance of climate change were heard throughout the interviews in Luleå. Nearly every interviewee mentioned the importance of climate change. This is also consistent with survey data in Sweden, which shows that there is widespread support for combating climate change (Gullers Grupp 2018).

In contrast, a lack of broad public support was mentioned as a major barrier to DE projects in Anchorage and Saskatoon. A representative from the environmental community in Saskatoon mentioned that a lack of leadership on climate change makes it difficult for the city to move forward with local energy initiatives. 
Unfortunately, none of the political parties are doing a ton, but in Saskatchewan in particular the need to oppose anything the federal government is doing, the need to [...] deny climate change issues leads to no leadership from the province. And so, in terms of energy generation, energy conservation $[\ldots]$ there's very little happening. And then from the municipal point of view, I think one of the resistances is the amount of work it could take for the city to do something on their own without the support from the province. So, for example, building code, the city municipalities can set their own building code, but Saskatoon's like, oh are you kidding me? The amount of work to have our own building codes separate from the province is just kind of too much. And then they also worry about things like people building outside of the city instead of in the city to save a few bucks on construction (Saskatoon Interview \#2).

Climate change was minimally mentioned in Anchorage. Of the 32 interviews, only two talked about the attitudes towards and worries about climate change as impacting DE in the city. This contrasts with interviews in Luleå, where nearly all interviewees emphasized the importance of climate change. One interviewee from Anchorage, a representative for one of the utilities, discussed the importance of focusing on fuel savings instead of climate change to garner more support.

There're definitely people in the state that don't agree with and believe climate change is happening. So, they don't want to pay more for their electricity around renewables. But if we can all agree burning less as is good, then everybody, no matter what their motivation is served. Whether it's cost, whether it's climate change, whether it's energy security, burning less fuel is good (Anchorage Interview \#13). 


\section{Discussion}

The purpose of this paper is to understand the governance challenges for DE transitions in cities. Based on interview data and grey literature review, the results below highlight the impacts of the five governance dimensions: utility market structure, multi-sector cooperation, decision-making autonomy and capacity, multilevel governance, and public perceptions on climate change. These governance dimensions and their impact on acceleration DE transitions will be explored in this section.

\subsection{Utility market structure}

Large technological systems like the electricity sector tend to move incrementally and are resistant to potentially disruptive innovations (Hughes 1983; Markard, Truffer 2006). However, the recent trend towards the liberalization and deregulation of electric markets have fundamentally restructured the operations of utilities, as in the case of Sweden. Market deregulation can be supportive to DE such as providing generation options and a market for selling local power (Carley 2009; Muratori et al. 2014). Deregulation of the energy markets has also been shown to reduce $R \& D$ funding for innovative energy technologies (Dooley 1998). Deregulated markets can permit new competition and differentiation of firms. Delmas et al have found that this differentiation can result in consumer preference for 'green' energy options, however this result is contingent a public preference for these energy options (Delmas et al. 2007). The results from the interviews also suggest that utility market structure can impact the opportunities for DE projects (see Table 3). Consistent with the literature, there are both opportunities and challenges with the deregulation of the electric market.

More important than the market type is the transmission functionality. In Anchorage, the lack coordination and oversight of the transmission system drew significant challenges for DE. Each electric utility in Anchorage is vertically integrated with their own transmission system. This creates a collective action problem known as a prisoner's dilemma (Hardin 1971). Voluntary cooperation of the transmission system between the utilities are disincentivized at the individual 
level to the detriment of all of the utilities on the Railbelt collectively. In other words, the benefits to act in one's economic self-interest are outweighed by the uncertainty that the other actors using this common pool, the transmission system, may defect and act in their perceived self-interest. This theory presumes that actors within this system operate solely within a rational economic cost-optimization model. Despite the clear logic of this theory, empirical and human evolutionary evidence suggests that actors are often inclined to cooperate and trust each other in such instances (Ostrom 2000). Although it would appear that the utilities operated only within their self-interest, there have been decades long attempt by the Railbelt utilities to voluntarily cooperate and otherwise create a framework that would more efficiently coordinate the transmission system. For instance, there are already utilities on the Railbelt engaged in a loose power pool arrangement and have shared purchased agreements, which are managed and governed by the intertie agreement and the intertie management committee (Amended and Restated Alaska Intertie Agreement 2011; The Intertie Management 2017). This agreement, among others, is a start but not enough to facilitate a sufficient coordination of the transmission system to support a broader transition to DE. Given the longstanding inability of the utilities to cooperate, a combination of oversight by the state and self-organization would be necessary.

Table 3. Competitive utility market structure

\begin{tabular}{|l|l|l|l|}
\hline & Luleå & Saskatoon & Anchorage \\
\hline Market type & Deregulated & Regulated & Regulated \\
\hline $\begin{array}{l}\text { Transmission } \\
\text { functionality }\end{array}$ & Integrated & Integrated & Disjointed \\
\hline
\end{tabular}

\subsection{Multi-sector cooperation}

Emphasized by the interviewees in Luleå was that the success of their DE projects can be attributed to their cooperative approach (see Table 4). Long-term agreements and cooperation with the private sector, multiple levels of government, and the academy facilitated robust multi-sector cooperation. As a result, the system 
in Luleå is a large system of well entrenched institutional actors. This contrasted to Saskatoon and Anchorage where there was moderate multi-sector cooperation and siloed institutions. However, Saskatoon and Anchorage had many more new actors in the DE arena in the last 10 years. Perhaps an offset to the lack of cooperation in Anchorage and Saskatoon was a surge in activity of new actors. Largely nonexistent in Luleå, these actors were motivated to solve the principal-agent collective action problem that existed within their siloed sectors. There was a perceived benefit to be garnered by cooperating between public-private and public-public entities, and these actors were motived to build this capacity within their city.

Table 4. Comparative institutional integration

\begin{tabular}{|l|l|l|l|}
\hline & Luleå & Saskatoon & Anchorage \\
\hline $\begin{array}{l}\text { Multi-sector } \\
\text { cooperation }\end{array}$ & High & Moderate & Moderate \\
\hline New actors & Low & High & High \\
\hline
\end{tabular}

But what can explain the lack of new actors in Lulea and the emergence of new actors in Anchorage and Saskatoon? Actors within a highly cooperative system as with Luleå create co-dependence and have increased overall actors (Emerson 1962; Whetten, Rogers 1982). In fact, cooperation can create an institutional structure that affords opportunity and power to those within the cooperative network - and not to those outside (Moe 2005). The result of these interactions are stability of the system and a resistance to the emergence of new actors. Even facing failure, these interdependent actors persist (Klijn, Teisman 2003). This was seen in Luleå with the failure of their waste-to-gas project. Actors on the periphery as well as those directly involved with the project recognized that this project was a failure. This did not stop the project to continue despite revenue losses for a decade and alternatives (i.e. electric mobility) that would pose further risk to the project. This may explain the lack of actors in Luleå and the larger number of actors in Anchorage and Saskatoon.

Another explanation for the lack of new actors would be that the system in Luleå functions well and new actors may see less value in contributing in such a system - there is strong social self-organization in Luleå. My interviews and 
interactions with the environmental community in Luleå would support this claim. By virtue of their role in society, environmental activists are quick to point out flaws within systems and suggest alternatives. In Luleå, the environmental community spent little by way of critiquing Luleå's performance, which was a stark contrast to their counterparts in Saskatoon and Anchorage. The environmental community in Luleå focused their efforts on mining operations in the northern region of Sweden. When asked about the city of Luleå, they noted that the city was moving in the right direction. The perception that the city was progressing was supported by all interviewees in Luleå.

These two explanations can be mutually supportive. High levels of multi-sector cooperation could both facilitate the success of progress in the city while also leading to networks of interdependent actors resistant to new entrants. And the success of the network to achieve its goals leads in turn to new actors not seeing a benefit to disrupt the system. In this case, the success of the cooperative approach leads to an inherent weakness, albeit one that may not be overly concerning given the progress made in Luleå.

\subsection{Decision-making capacity and autonomy}

The three cities have varying degrees of decision-making capacity and autonomy. Swedish cities have considerable resources at their disposal, relative to their Canadian and American counterparts. Since the 1980s, the Swedish government has promoted increased local economic development which has afforded municipalities more responsibility over business development and innovation. The general differences of decision-making capacity and autonomy is summarized in Table 5. What can be said from this general comparison is that autonomy and capacity need to meet in order facilitate a DE transition. The Anchorage case demonstrates that autonomy alone without the underpinning capacity is not sufficient - which was evident from the interviewee's responses in Anchorage.

The ability for local entities to be involved in decision-making and have the capacity to execute DE projects is a strategy, purposeful or not, to mitigate the challenges of complexity. DE transitions are complex and how they emerge is 
diverse and locally specific. Local energy projects are a feature of their geography, infrastructure, and history. In Luleå, the district heating system is fed as a byproduct from the local steel plant, the Swedish publicly owned company SSAB (Petrini et al. 2004). There are further efficiencies within the system through a CHP system that also provides electricity to the local electric utility, Luleå Energi. Actors within the city would likely be the most capable facilitators to leverage their local attributes of these complex system interactions. This analysis is also consistent with recent comparative work on local energy transitions in towns. Bayulgen has pointed that municipal government structure has limited impact as a driver but bureaucratic capacity is a determinative driver (Bayulgen 2020).

Table 5. Comparative decision-making capacity and autonomy

\begin{tabular}{|l|l|l|l|}
\hline & Luleå & Saskatoon & Anchorage \\
\hline Capacity & High & Moderate & Low \\
\hline Autonomy & Moderate & Moderate & High \\
\hline
\end{tabular}

To be clear, decision-making capacity and autonomy are alone not enough they are factors. It would be an over simplification to suggest otherwise. In fact, research on collaboration between industry and municipalities in Sweden emphasizes that their success relies heavily on the people involved in the projects (Grönkvist, Sandberg 2006), which was in particular the case in Luleå (Söderholm 2018). But again, the foundation of this success in contingent on having both autonomy and capacity in place.

\subsection{Multilevel governance}

With multilevel governance, the implications are somewhat counterintuitive. On the one hand, policy stability and support from higher level governments can create a foundation for DE transitions to occur. Actors and institutions can plan and build the necessary capacity to move objectives forward. On the other hand, a lack of policy stability and fluctuating support from higher level government can create a window of opportunity for DE transitions. The results from this study suggest that support from higher-level government is important but not essential. In Anchorage, 
actors respond quickly to policy windows because there is uncertainty on the stability of newly adopted policies in Alaska, given the natural resource market fluctuations and state level decision-making.

Table 6. Comparative multilevel governance

\begin{tabular}{|l|l|l|l|}
\hline & Luleå & Saskatoon & Anchorage \\
\hline Policy stability & High & Moderate & Low \\
\hline $\begin{array}{l}\text { Support from higher- } \\
\text { level governments }\end{array}$ & High & Moderate & Moderate \\
\hline
\end{tabular}

A potential explanation is that windows of opportunity can create openings for disruptive innovations to occur (Geels 2002, 2014; Geels et al. 2017). These windows of opportunity need to be severe and urgent enough to create a focusing event amongst actors (Kingdon 1984; Brikland 1998). The policy instability in Anchorage created a response by groups of actors wanting to fill this gap. The Renewable Energy Alaska Project (REAP), for instance, is a highly innovative and prominent organization that has had strong impact on public policy in the city and state. These policy entrepreneurs ${ }^{8}$ are often important actors in moving forward innovative policy (Roberts, King 1991; Mintrom 1997; Christopoulos 2015). Amongst other accomplishments, REAP played a key role with the establishment of Bill 162 (which established the Renewable Energy Grant Fund), Bill 289 (which provided \$360 USD towards energy efficiency), and Bill 306 (which included a 50\% by 2025 renewable energy target). These changes at the state level had impacts on Anchorage's energy system and were a function of the political and policy ebbs and flows.

\subsection{Public perceptions on climate change}

The interviewees concern on the public perception of climate change (see Table 7) and the impact this has on policy is consistent with the literature. Similar to the results, perceptions of climate change vary from country-to-country (Wolf, Moser

\footnotetext{
8 Policy entrepreneurs, "use several activities to promote their ideas. These include identifying problems, shaping the terms of policy debates, networking in policy circles, and building coalitions" (Mintrom, Vergari 1996: 423).
} 
2011). In Sweden, there is large public support for climate change (Wibeck 2014). In both Alaska and Saskatchewan public support is moderate to low (Mildenberger et al. 2016).

Table 7. Comparative public perceptions on climate chance

\begin{tabular}{|l|l|l|l|}
\hline & Luleå & Saskatoon & Anchorage \\
\hline Public perception & High & Moderate & Low \\
\hline
\end{tabular}

Public acceptance of climate change can impact the governance of DE transitions. In Anchorage in particular, there were attempts by project proponents to reframe projects in terms of economic benefits, which changed the justification for projects to move forward. Whereas in Luleå, great emphasis was placed on emissions reductions benefits of DE projects as well as economic considerations.

Public support for climate change can motivate support for climate policies. For instance, research suggests that support for climate policy varies with type of policy (Shwom et al. 2010; Rhodes et al. 2017) and how the issues of climate change are framed (Nisbet 2009; Shwom et al. 2010; Mccright et al. 2016; Feldman, Hart 2018; Stecula, Merkley 2019). Part of the reason this occurs is because people can psychologically resistant to climate change (Swim et al. 2011; Van Boven et al. 2018) and motivated by a particular political ideology (Mccright, Dunlap 2011; Van Boven et al. 2018).

\section{Conclusion}

Cities do not operate as silos or islands. They are integrated within a jurisdictional context that has governance implications, which impact how DE projects unfold and the dynamics in which they are situated. As the results of this study demonstrate, the success of DE projects care be impacted by cities' governance differences. The jurisdictions from which cities reside have political, cultural, legal, and policy practices and norms that can enable or hinder DE transitions. This paper asked the question: How does governance impact the 
acceleration of decentralized energy transitions in cities? To investigate this question, this paper compared five governance dimensions with their impact on DE transitions in cities: 1) utility market structure, (2) multi-sector collaboration, (3) decision-making capacity and autonomy, (4) multilevel governance, and (5) public perceptions of climate change. The results from this research showed that there are important determining factors within the governance dimensions. Public perception of climate change, supportive and stable government interventions, multi-sector collaboration, and local capacity are important determining factors to DE transitions. The results also showed that there are elements of the five governance dimensions that are not a determining factor in all cases, such as local autonomy, utility ownership structure, new actors.

This paper began by suggesting that governance hierarchies, markets, and networks have all been used to explain DE innovations and asked the question, "How does governance impact decentralized energy transitions in cities?". Upon starting this research project, it was hypothesized that networked governance would be the preferred arrangement to facilitate DE transitions. Given the stylized similarity of decentralization and networks, as well as the mainstream trend towards the "internet of things", I perceived that there may be alignment. However, my investigation into this topic has illuminated deeper and more nuanced insights. It is the case that networked governance is synergistic with DE transitions. The multisector collaboration in Luleå and the policy communities in Saskatoon and Anchorage show that these networks of actors can motivate DE transitions. It is also the case, though, that direct support from public institutions was important. In all cities, in fact, there was financial and managerial support for innovative DE projects and interviewees consistently emphasized that much of this support was necessary as it reduced the upfront financial burden of their projects. And finally, actors and organizations were able to capitalize on markets to move DE projects forward, the utility market structure in Luleå as the obvious example. Actors in Anchorage, particularly in the business and advocacy organizations, were able to deliver innovative DE projects despite a lack of direction from higher-level governments and weak actor networks. 
In answering this question of governance and DE more precisely, I would bring this discussion back to the governance work from two decades ago. It was Powell who challenged the notion that governance falls within a continuum between a market and a hierarchy and suggested that governance can also fall within a third category: a network (Powell 1990). He observed that some sectors in society function well because of their network governance structure. His work laid the foundation for future research on network governance and a deeper appreciation of less formal organizational interactions and the power of human reciprocity. Powell's astute observation that we should consider a multitude of governance arrangements is correct. However, it could be expanded. His work focused on organizational sectors which is limited for an analysis involving multi-sector arenas like DE transitions. My observations have shown that interactions between governance dimensions may be just as relevant as the three categories of governance. There is a multiplicity of governance arrangements that can drive or hinder DE transitions. This work has outlined five governance dimensions but there are likely more. But the more promising insight is that the interactions of these governance dimensions may offer a more powerful explanation for DE transitions.

A revised focus on governance interactions can lead to further questioning. For instance, to what extent does the interaction between public perceptions of climate change and multi-sector collaboration facilitate DE transitions? Are policy communities more effective at facilitating DE transitions in regulated or deregulated utility markets? How much does city level autonomy and capacity impact DE transitions when there is strong support from higher-level governments? These questions, among others, that focus on the interactions of governance dimensions can be explored to offer further insights into the conditions that facilitate DE transitions.

I must end with a note on the limitations of this work. This research involved only three cases and therefore it is difficult to make generalizable claims. Ragin has presented a caveat for such instances, arguing that "case-oriented researchers are always open to the charge that their findings are specific to the few cases they examine, and when they do make broad comparisons and attempt to generalize, they often are accused of letting their favorite cases shape or at least color their 
generalizations" (Ragin 2014: ix). Although I was cautious not to fall victim to Ragin's caveat of favouritism bias, there were a limited number of cases and therefore the major claims in this analysis leave it open to understandable scrutiny. The claims presented in this analysis should be considered a starting place for further inquiry on the question of comparative research on urban energy transitions and governance.

\section{Acknowledgements}

This research is supported by the Social Sciences and Humanities Research Council of Canada. I would like to thank the interviewees for this research who kindly provided their time to support this project. Finally, I would like to thank Dr. Jeremy Rayner for his constructive comments and encouragement throughout the preparation of this research project and paper.

\section{References}

Akorede M.F., Hizam H., Pouresmaeil E. (2010), Distributed energy resources and benefits to the environment, "Renewable and Sustainable Energy Reviews", vol. 14 no. 2, pp. 724-734.

Alaska Department of Revenue (2017), Production history and forecast by production area from Fall, http://www.tax.alaska.gov/sourcesbook/AlaskaProduction.pdf [13.03.2020].

Alaska Housing Finance Corporation (2018), Goal program. Rating and award criteria plan, https://www.ahfc.us/application/files/4515/0171/3191/goal_pp_051217.pdf, s. 3 [13.03.2020].

Alaska Public Utilities Commission (1998), Power pooling / Central dispatch planning study, http://rca.alaska.gov/RCAWeb/Documents/Electric/PowerPooling.pdf [13.03.2020].

Aldiabat K.M., Le Navenec C.-L. (2018), Data saturation. The mysterious step in grounded theory methodology, "The Qualitative Report", vol. 23 no. 1, pp. 245-261.

Amended and Restated Alaska Intertie Agreement (2011), https://www.sec.gov/Archives/edgar/data/878004/000119312512123010/d317480dex10151.htm [13.03.2020].

Andrews R., Boyne G.A., Andrews R. (2016), Capacity, leadership, and organizational performance. Testing the black box model of public management, "Public Administration Review", vol. 70 no. 3, pp. 443-454. 
Annink A. (2016), Using the research journal qualitative data collection in a cross-cultural context, "Entrepreneurship Research Journal", vol. 7 no. 1.

Baker S., Waterfield J., Bartlam B. (2018), Saturation in qualitative research. Exploring its conceptualization and operationalization, "Quality and Quantity", vol. 52 no. 4, pp. 1893-1907.

Bayulgen O. (2020), Localizing the energy transition. Town-level political and socio-economic drivers of clean energy in the United States, "Energy Research and Social Science", vol. 62.

Betsill M., Bulkeley H. (2004), Transnational networks and global environmental governance. The cities for climate protection program, "International Studies Quarterly", vol. 48 no. 2, pp. 471-493.

Betsill M., Bulkeley H. (2007), Looking back and thinking ahead. A decade of cities and climate change research, "Local Environment", vol. 12 no. 5, pp. 447-456.

Block E.S., Erskine L. (2012), Interviewing by telephone. Specific considerations, opportunities, and challenges, "International Journal of Qualitative Methods", vol. 11 no. 4, pp. 428-445.

Brikland T.A. (1998), Focusing Events, Mobilization, and Agenda Setting, "Journal of Public Policy", vol. 18 no. 1, pp. 53-74.

Bulkeley H., Metsill M.M. (2003), Cities and climate change. Urban sustainability and global environmental governance, Routledge, New York.

Byrne D. (2005), Complexity, configurations and cases, "Theory, Culture and Society", vol. 22 no. 5 , pp. 95-111.

Carley S. (2009), State renewable energy electricity policies. An empirical evaluation of effectiveness, "Energy Policy", vol. 37 no. 8, pp. 3071-3081.

Chittum A., Østergaard P.A. (2014), How Danish communal heat planning empowers municipalities and benefits individual consumers, "Energy Policy", vol. 74(C), pp. 465-474.

Christopoulos D. (2015), Exceptional or just well connected? Political entrepreneurs and brokers in policy making, "European Political Science Review", vol. 7 no. 3, pp. 475-498.

City of Saskatoon (2017), Facilitating Solar Energy Opportunities in Saskatoon, https://pubsaskatoon.escribemeetings.com/filestream.ashx?DocumentId=53202 [13.03.2020].

Compact of Mayors (2015), Compact of Mayors, doi: 10.1017/CBO9781107415324.004.

Company A.T. (2019), Railbelt utilities seek regulatory approval to form transmission utility, News Release, https://www.atcllc.com/whats-current/railbelt-utilities-seek-regulatory-approval-to-formtransmission-utility/ [13.03.2020].

Delmas M., Russo M.V., Montes-Sancho M. J. (2007), Deregulation and environmental differentiation in the electric utility industry, "Strategic Management Journal", vol. 28 no. 2, pp. 189-209.

Dolter B.D., Boucher M. (2018), Solar energy justice. A case-study analysis of Saskatchewan, Canada, "Applied Energy", vol. 225, pp. 221-232. 


\section{GOVERNANCE AND DECENTRALIZED ENERGY TRANSITIONS ...}

Dooley J.J. (1998), Unintended consequences. Energy R\&D in a deregulated energy market, "Energy Policy", vol. 26 no. 7, pp. 547-555.

Droege P. (2002), Renewable energy and the city. Urban life in an age of fossil fuel depletion and climate change, "Bulletin of Science, Technology \& Society", vol. 22 no. 2, pp. 87-99.

Emerson R.M. (1962), Power-dependence relations, “American Sociological Association”, vol. 27 no. 1, pp. 31-41.

Feldman L., Hart P.S. (2018), Climate change as a polarizing cue. Framing effects on public support for low-carbon energy policies, "Global Environmental Change", vol. 51, pp. 54-66.

Florini A., Sovacool B.K. (2009), Who governs energy? The challenges facing global energy governance, "Energy Policy", vol. 37 no. 12, pp. 5239-5248.

Fossey E. et al. (2002), Understanding and evaluation qualitative research, "Australian and New Zealand Journal of Psychiatry", vol. 36, pp. 717-732.

Gargan J.J. (1981), Consideration of local government capacity, "Public Administration Review”, vol. 41 no. 6 , pp. $649-658$.

Geels F.W. (2002), Technological transitions as evolutionary reconfiguration processes. A multi-level perspective and a case-study, "Research Policy", vol. 31 no. 8-9, pp. 1257-1274.

Geels F.W. (2014), Regime resistance against low-carbon transitions. Introducing politics and power into the multi-level perspective, "Theory, Culture \& Society", vol. 31 no. 5, pp. 21-40.

Geels F.W. et al. (2017), The socio-technical dynamics of low-carbon transitions, "Joule", vol. 1 no. 3 , pp. 463-479.

Glaser B.G., Strauss A.L. (1999), Discovery of grounded theory, Routledge, New York.

Grönkvist S., Sandberg P. (2006), Driving forces and obstacles with regard to co-operation between municipal energy companies and process industries in Sweden, "Energy Policy", vol. 34 no. 13, pp. 1508-1519.

Guest G., Bunce A., Johnson L. (2006), How many interviews are enough? An experiment with data saturation and variability, "Field Methods", vol. 18 no. 1, pp. 59-82.

Gullers Grupp (2018), The public's views on climate change 2018. A quantitative survey of the Swedish public's view on climate solutions, The public's views on climate change 2018. A quantitative survey of the Swedish public's view on climate solutions [13.03.2020].

Hardin R. (1971), Collective action as an agreeable n-prisoners, "Behavioral Science”, vol. 11, pp. 203481.

Hennink M.M., Kaiser B.N., Marconi V.C. (2017), Code saturation versus meaning saturation. How many interviews are enough?, "Qualitative Health Research", vol. 27 no. 4, pp. 591-608. 
Hodson M., Marvin S. (2009), Urban ecological security: a new urban paradigm?, "International Journal of Urban and Regional Research", vol. 33 no. 1, pp. 193-215.

Holt A. (2010), Using the telephone for narrative interviewing: a research note, "Qualitative Research", vol. 10 no. 1, pp. 113-121.

Hommels A. (2005), Studying obduracy in the city. Toward a productive fusion between technology studies and urban studies, "Science, Technology \& Human Values", vol. 30 no. 3, pp. 323-351.

Hughes B. R., Chaudhry H.N., Ghani S.A. (2011), A review of sustainable cooling technologies in buildings, "Renewable and Sustainable Energy Reviews", vol. 15 no. 6, pp. 3112-3120.

Hughes T. P. (1983), Networks of power. Electrification in Western society, 1880-1930, Johns Hopkins University Press, Baltimore - London.

Hurlbert M. et al. (2019), Transitioning from coal. Toward a renewables-based socio-technical regime in Saskatchewan, "Environmental Innovation and Societal Transitions", in press, doi: 10.1016/j.eist.2019.11.005.

Hurlbert M., McNutt K., Rayner J. (2010), Policy pathways. Transitioning to sustainable power generation in Saskatchewan, "Renewable Energy Law \& Policy Review", vol. 1 no. 1, pp. 87-100.

IEA (2009), Cities, towns \& renewable energy: yes in my front yard, http://www.iea.org/publications/freepublications/publication/Cities2009.pdf [13.03.2020].

IPCC (2007), Summary for policymakers, climate change 2014, mitigation of climate change, Contribution of Working Group III to the Fifth Assessment Report of the Intergovernmental Panel on Climate Change, Cambridge University Press, Cambridge - New York.

Janesick V.J. (1999), A journal about journal writing as a qualitative research technique. History, issues, and reflections, "Qualitative Inquiry", vol. 5 no. 4, pp. 505-524.

Jiang L., O’Neill B.C. (2017), Global urbanization projections for the shared socioeconomic pathways, "Global Environmental Change", vol. 42, pp. 193-199.

Kallio H. et al. (2016), Systematic methodological review. Developing a framework for a qualitative semi-structured interview guide, "Journal of Advanced Nursing", vol. 72 no. 12, pp. 2954-2965.

Keirstead J., Jennings M., Sivakumar A. (2012), A review of urban energy system models. Approaches, challenges and opportunities, "Renewable and Sustainable Energy Reviews", vol. 16 no. 6, pp. 38473866 .

Kemp R., Schot J., Hoogma R. (1998), Regime shifts to sustainability through processes of niche formation. The approach of strategic niche management, "Technology Analysis \& Strategic Management”, vol. 10 no. 2, pp. 175-198.

Kingdon J. (1984), Agenda, alternatives, and public policies, Addison-Wesley Educational Publishers, Boston.

Klijn E.H., Teisman G.R. (2003), Institutional and strategic barriers to PPP. An analysis of Dutch case, "Public Money \& Management", vol. 23 no. 3, pp. 137-146. 


\section{GOVERNANCE AND DECENTRALIZED ENERGY TRANSITIONS ...}

Köhler J. et al. (2019), An agenda for sustainability transitions research. State of the art and future directions, transitionsnetwork.org, pp. 1-66 [13.03.2020].

Lancaster K. (2017), Confidentiality, anonymity and power relations in elite interviewing. Conducting qualitative policy research in a politicised domain politicised domain, "International Journal of Social Research Methodology”, vol. 20 no. 1, pp. 93-103.

Lesage D., Van de Graaf T., Westphal K. (2010), Global energy governance in a multipolar world, Ashgate Publishing, London - New York.

Lin B., Ouyang X. (2014), Energy demand in China. Comparison of characteristics between the US and China in rapid urbanization stage, "Energy Convers", vol. 79, pp. 128-139.

Luleå Kummun (2020), https://www.lulea.se/ [13.03.2020].

Malterud K., Siersma V.D., Guassora A.D. (2016), Sample size in qualitative interview studies: guided by information power, “Qualitative Health Research”, vol. 26 no. 13, pp. 1753-1760.

Markard J., Raven R., Truffer B. (2012), Sustainability transitions. An emerging field of research and its prospects, "Research Policy", vol. 41 no. 6, pp. 955-967.

Markard J., Truffer B. (2006), Innovation processes in large technical systems. Market liberalization as a driver for radical change?, "Research Policy", vol. 35 no. 5, pp. 609-625.

Mccright A.M. et al. (2016), Ideology, capitalism, and climate. Explaining public views about climate change in the United States, "Energy Research \& Social Science", vol. 21, pp. 180-189.

Mccright A.M., Dunlap R.E. (2011), The politicization of climate change and polarization in the American's views of global warming, 2001-2010, "The Sociological Quarterly", vol. 52 no. 2, pp. 155194.

Mildenberger M. et al. (2016), The distribution of climate change public opinion in Canada, "PLoS ONE", vol. 11 no. 8 .

Mill J.S. (1843), A system of logic, ratiocinative and inductive, https://www.gutenberg.org/files/27942/27942-pdf.pdf [13.03.2020].

Mintrom M. (1997), Policy entrepreneurs and the diffusion of innovation, "American Journal of Political Science", vol. 41 no. 3, pp. 738-770.

Mintrom M., Vergari S. (1996), Advocacy coalitions, policy entrepreneurs, and policy change, "Policy Studies Journal", vol. 24 no. 3, pp. 420-435.

Moe T.M. (2005), Power and political institutions, "Perspectives on Politics", vol. 3 no. 2, pp. 215-233, http://journals.cambridge.org/download.php?file=\%2FPPS\%2FPPS3_02\%2FS1537592705050176a.pd f\&code=2ffe $3 \mathrm{bf} 159 \mathrm{~d} 21 \mathrm{~d} 14 \mathrm{f} 111 \mathrm{c} 69 \mathrm{~b} 82140018$ [13.03.2020].

Morse J.M. (1995), Editorial: the significance of saturation, "Qualitative Health Research”, vol. 5 no. 2 , pp. 147-149. 
Mulugetta Y., Jackson T., van der Horst D. (2010), Carbon reduction at community scale, "Energy Policy", vol. 38 no. 12, pp. 7541-7545.

Muratori M., Schuelke-Leech B.A., Rizzoni G. (2014), Role of residential demand response in modern electricity markets, "Renewable and Sustainable Energy Reviews", vol. 33, pp. 546-553.

Nisbet M. (2009), Communicating climate change. Why frames matter for public engagement, "Environmental Magazine", vol. 51 no. 2, pp. 12-23.

Ortlipp M. (2008), Keeping and using reflective journals in the qualitative research process, "The Qualitative Report", vol. 13 no. 4, pp. 695-705.

Ostrom E. (2000), Collective action and the evolution of social norms, "The Journal of Economic Perspectives", vol. 14 no. 3, pp. 137-158.

Petrini H. et al. (2004), Energy network SSAB - LuleKraft - City of Luleå. Two decades' experience of co-production of steel, electric power and district heating', Scanmet II: 2nd International Conference on Process Development in Iron and Steelmaking, 6-8 June 2004.

Powell W.W. (1990), Neither market nor hierarchy. Network forms of organization, "Research in Organizational Behavior", vol. 12, pp. 295-336.

Ragin C.C. (2014), The comparative method. Moving beyond qualitative and quantitative strategies, 2nd ed., University of California Press, Berkeley.

Rhodes E., Axsen J., Jaccard M. (2017), Exploring citizen support for different types of climate policy, "Ecological Economics", vol. 137, pp. 56-69.

Rihoux B. et al. (2013), From niche to mainstream method? A comprehensive mapping of QCA applications in journal articles from 1984 to 2011, "Political Research Quarterly", vol. 66 no. 1, pp. 175-184.

Roberts N.C., King P.J. (1991), Policy entrepreneurs. Their activity structure and function in the policy process, "Journal of Public Administration Research and Theory", vol. 1 no. 2, pp. 147-175.

Robinson O.C. (2014), Qualitative research in psychology sampling in interview-based qualitative research. A theoretical and practical guide, "Qualitative Research in Psychology", vol. 11, pp. 25-41.

Saunders B., Kitzinger J. (2015), Anonymising interview data. Challenges and compromise in practice, "Qualitative Research", vol. 15 no. 5, pp. 616-632.

Schober M. (2018), The future of face-to-face interviewing, "Quality Assurance in Education”, vol. 26 no. 2 .

Seyfang G., Park J.J., Smith A. (2013), A thousand flowers blooming? An examination of community energy in the UK, "Energy Policy", vol. 61, pp. 977-989.

Shwom R. et al. (2010), Understanding U.S. public support for domestic climate change policies, "Global Environmental Change", vol. 20 no. 3, pp. 472-482. 


\section{GOVERNANCE AND DECENTRALIZED ENERGY TRANSITIONS ...}

Söderholm K. (2018), Pioneering industry / municipal district heating collaboration in Sweden in the 1970s', "Energy Policy", vol. 112, pp. 328-333.

Statistics Canada (2016), Population and dwelling count highlight tables, 2016 Census, https://www12.statcan.gc.ca/census-recensement/2016/dp-pd/hlt-fst/pd-pl/Table.cfm [13.030.2020].

Stecula D.A., Merkley E. (2019), Framing climate change. Economics, ideology, and uncertainty in American news media content from 1988 to 2014, "Frontiers in Communication”, no. 4, pp. 1-15.

Swim J.K. et al. (2011), Psychology's contributions to understanding and addressing global climate change, "American Psychologist", vol. 66 no. 4, pp. 241-250.

The Intertie Management: Committees' Railbelt Operating and Reliability Standards (2017), doi=10.1.1.307.964 [13.03.2020].

Tilley L., Woodthorpe K. (2011), Is it the end of anonymity as we know it? A critical examination of the ethical principle of anonymity in the context of 21st century demands on the qualitative reseacher, "Qualitative Research", vol. 11 no. 2, pp. 197-212.

Tilly C. (1984), Big structures, large processes, huge comparisons, Russell Sage Foundation, New York.

United Nations (2010), World urbanization prospects. The 2009 revision, population and development review, https://www.ipcc.ch/apps/njlite/ar5wg2/njlite_download2.php?id=10148 [13.03.2020].

United Nations (2018), 68\% of the world population projected to live in urban areas by 2050, says UN, Department of Economic and Affairs, https://www.un.org/development/desa/en/news/population/2018-revision-of-world-urbanizationprospects.html [13.03.2020].

United States Census Bureau (2019), Population and housing unit estimates, https://www.census.gov/programs-surveys/popest.html [13.03.2020].

Van Boven L., Ehret P.J., Sherman D.K. (2018), Psychological barriers to bipartisan public support for climate policy, "Perspectives on Psychological Science", vol. 13 no. 4, pp. 492-507.

Watt D. (2007), On becoming a qualitative researcher. The value of reflexivity, "The Qualitative Report", vol. 12 no. 1, pp. 82-101.

Whetten D., Rogers D. (1982), Interorganizational coordination. Theory, research, and implementation, Iowa State University Press, Ames.

Wibeck V. (2014), Social representations of climate change in Swedish lay focus groups. Local or distant, gradual or catastrophic?, "Public Understanding of Science", vol. 23 no. 2, pp. 204-219.

Wolf J., Moser S.C. (2011), Individual understandings, perceptions, and engagement with climate change. Insights from in-depth studies across the world, "Wiley Interdisciplinary Reviews: Climate Change", vol. 2 no. 4 , pp. 547-569.

Wurzel R.K.W. et al. (2019), Climate pioneership and leadership in structurally disadvantaged maritime port cities, "Environmental Politics", vol. 28 no. 1, pp. 146-166. 